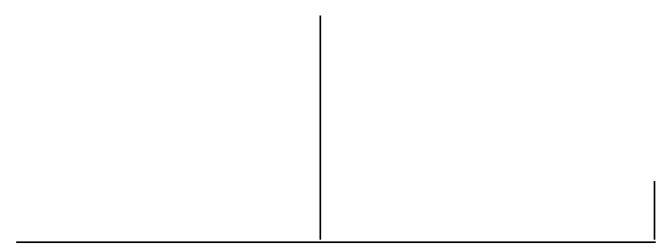

Rev. Latinoam. Psicopat. Fund., VII, 2, 29-48

\title{
Psychotherapy: from exorcism to cognitive theories
}

Durval Mazzei Nogueira Filho

The author discusses aspects of psychotherapeutic action. He defends the rationality of the procedure, comments on the splintering of the field of psychotherapy and discusses the usefulness of applying the scientific methodology to this field of knowledge.

Key words: Psychotherapy, psychoanalisis, research, science 


\section{Introduction}

Psychotherapy is an uncomfortable problem for psychiatry. There are three types of reasons for making this unusual, but categorical assertion. The first is that therapy is exercised by members of a number of professions other than those trained in medicine, including psychologists, philosophers, pedagogues and nurses.

A second aspect is the exercise of psychotherapy itself. Psychotherapy brings to the core of therapeutic action aspects that are considered accessory by medically oriented therapy (even though these aspects are seen as conditions for the efficiency of treatment). In other words, attention, orientation, interpretation, punctuation, and concern for others are more than the simple setting where medical knowledge is put into practice (Campos et al., 2001 \& Jaspers, 1998). Psychotherapy can, in fact, define its mode of action and its mechanism for treatment on the basis of these elements.

The third point is the most delicate, and is the pivot point for much of the contemporary discussion going on about this topic. I am referring here to the contemporary technological and neurobiological developments that are designed to replace psychotherapeutic action, based on doubts as to whether such successful treatment can actually take place unless some specific and demonstrable fact in the biological body can be unquestionably verified.

In this regard, psychotherapy, although well-known and widely practiced, has not been uniformly welcomed in the medical field. This lack of uniformity explains the broad range of opinions in its regard, even in times past when its respectability was rarely questioned. 


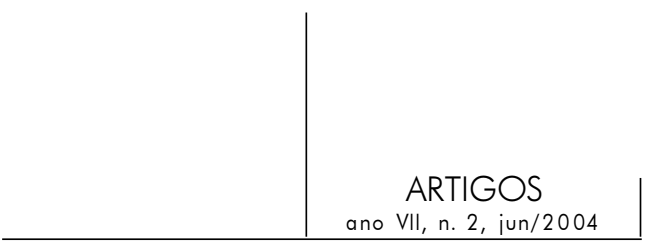

Thus, ever since the classical era of psychiatry, theoreticians have taken varied positions that reveal the multiplicity of opinions regarding the relevance of psychotherapy to medical discourse. In Ey (1974), psychotherapy defines, distinguishes and specifies psychiatry as a medical specialty. Nobre de Melo (1979) and Delgado (1969), however, do not espouse the same enthusiasm, and privilege clinical work and explicit medical discourse, preferring to classify psychotherapy as an auxiliary resource. Jaspers (1973) insists on the vital dimension of psychotherapy and places psychiatrists as the specialists among the other branches of medicine who are able to see the patient beyond his or her biological dimension. The very specific reason for this position is that the refusal to reduce the subject to merely natural occurrences is an integral part of psychiatric activity.

This debate continues in present-day literature. Wiener (1994) states that, by the very nature of psychiatry, we psychiatrists are more diverse than other medical specialists. This author does not wish to see the robust energy generated by the biological revolution become the only source of credibility for psychiatrists, relegating psychotherapy to a status of less importance. Andreasen (1996) also recognizes the bi-faceted character of psychiatry, indicating that it responds for both the correction of biological processes in the body and of psychosocial processes in the mind. Almost repeating Ey, Andreasen then admits that the psychiatrist's special skill is to approach and treat the human aspects of his or her patients by using psychological techniques. Mann (1989) comments on the turbulent relationship between psychiatry and the rest of medicine, but rejects the opinion that our field is the domain of charlatans and mystifiers who should be ousted by neuroscience and by the empirical method. He recognizes that the schemes of diagnosis and treatment change, but that the psychiatrist's essential activity continues being the act of relating with patients in a deep, sensitive and understanding way. Mann says that it is in the conduction of psychotherapies that this activity is learned, reinforcing his standpoint by conceiving of psychotherapy as central to psychiatric training, meaning long-term therapy. Mohl et al. (1990) also comments on the relevance of psychotherapy to the field of medicine, and brings up the question as to whether this practice should be abandoned and whether neurobiology will make it obsolete and relegated to a position of outmoded mystification. Mohl believes not, and holds that neuroscience does not reduce the importance that the vital meaning of mental and behavioral phenomena (the specific objects of psychotherapeutic procedure) have for patients.

As can be seen, this contemporary debate repeats the dilemma that has accompanied psychiatry throughout its history. One could even ask whether psychotherapy should be recognized as an appropriate activity in the medical field. The novelty that has recently come to the fore in this debate can be found in the advance of neurobiological thinking over forms of clinical activity that were 


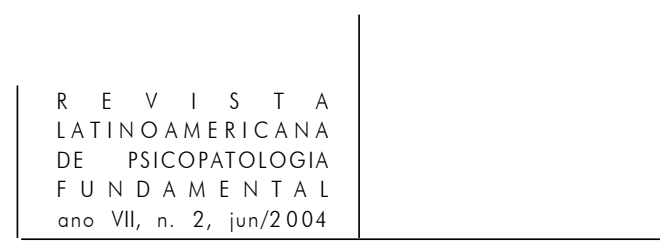

hitherto the exclusive object psychotherapeutic treatment. The psychotherapies have been forced to demonstrate their efficiency in comparison with treatments based on present-day literature and on neurobiological research (Marshall, 1980a, 1980b). The authors cited expressed their conviction that these more recent inroads do not exclude psychotherapy from the possible alternatives that medical therapeutics may employ for treating pathological conditions.

The risk that psychiatry is going through at this ideological moment is the construction of a false antinomy between the "old" - the psychotherapies - and the "modern" - meaning biological therapeutics, since many fail to recognize the vibrant and significant existence of this debate in the history of this branch of medical practice.

\section{Psychotherapy: a definition}

Most authors conceptualize psychotherapy as a procedure centered around communication, which is considered the clearest indication of the occurrence of an encounter between two human beings. But, as Ramadam indicates (1987), it is not just any quality of communication between two human beings that deserves the name of "encounter". If the encounter, even when meaningful and transforming, is merely episodic and/or non-systematic, it is not psychotherapy. If the encounter fails to tend toward producing change and leaves the terms that motivated the encounter unaltered, or if it adds further permanent suffering, it is not psychotherapy. Likewise, if the encounter does not promote transformation, it also cannot be considered psychotherapy. Thus, Ramadam defines psychotherapy as "all those therapeutic methods essentially based on systematized communication and relationship between the persons involved".

Etchegoyen (1977) adds that at least one of the persons involved in this specific encounter, the psychotherapist, should be familiar with an established theory of the personality and of mental illness (psychoanalysis, existential analysis, cognitive therapy, etc.), which serves as the basis for the communication technique applied. Therefore, psychotherapy is a procedure that entails the use of the word in an inter-relational context, based on a theoretical system, and having the objective of producing changes in pathological states.

Jaspers's definition should also be recalled. He describes psychotherapy as "all those methods of treatment that operate on the soul or on the body using means that address the soul. They all require the patient's willing cooperation" (Jaspers, 1998). Among these methods, Jaspers mentions suggestion, catharsis, exercises, education, and "methods with demands on the personality itself," where 


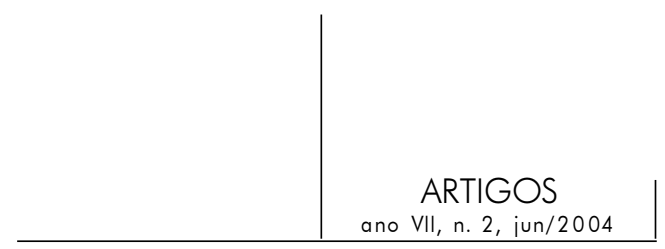

the physician must deal with "persons whose unconscious is confused, unstable, or suspect, and who are at enmity with their an unconscious and with themselves" (ibid.).

As can be seen, all the various ways of defining psychotherapy emphasize resorting to a range of influences which sustain that the word can operate on the body, provided that the communication with and complicity of the patient is a major factor. Under no circumstances can psychotherapy be reduced to the unilateral action of the therapist, as is possible in the prescription of medication or in carrying out surgery. This is the difference that characterizes psychotherapy and, at the same time, causes it to sometimes be confused with other activities that are not systematic, are not based on any theory of mental suffering or mental disorders, and are designed to influence the individual. It is not uncommon, for example, to hear the opinion that everyday activities such as "listening to good music" or "playing a game of soccer" correspond to "therapy". For psychotherapists with medical or any other type of formation, then, the task remains of explaining the difference and superiority of their various methods and their systematization regarding the daily events that undeniably affect comfort or discomfort in a given subject.

\section{Psychotherapy: a historical comment}

It is not uncommon to encounter references to psychotherapy as the heir to shamanic curing processes proper to primitive communities. The practice, common in Western religions, to seek out a dedicated religious, under the form of confession or a request for counseling, has also been compared with the psychotherapeutic act. In this sense, psychotherapy could be seen as the expropriation of a religious custom, a creative coalescence between primitive shamanism and monotheistic religions, expressed in secular terms.

In spite of the enormous differences in theory and method between psychotherapy and religion, the most sensible argument that sustains this comparison is the fact that the psychotherapist addresses the subject with nothing more than a word, a recommendation, a set of procedures, an interpretation, support, or a presence that would seem to depend exclusively on empathetic openness to the other. This attitude determines in the patient the construction of a number of expectations and of a particular state of influenceability and suggestionability that favors persuasion by the doctor.

This perspective is a two-edged sword.

On the one hand, it is cutting and deadly because it ignores the psychotherapist's logical discourse and his or her efforts to provide the population 


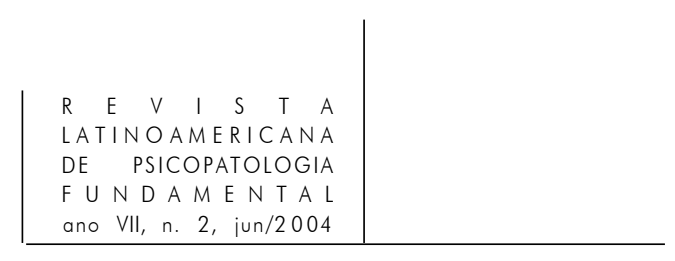

with a method of treatment, of one or another theoretical origin, reducing him or her to a mere charismatic holder of special skills. The other edge of the sword raises the psychotherapist to a special position, that of the theoretician who relies on transcendence as the constituting term of a subject, either when this latter is born and develops, when in health or when sick, and comes, with some degree of hope, to ask for help from another subject.

The possibility of confusion of this type has concerned some of the most outstanding thinkers in the field of therapy. Addressing an audience of young medical students, for example, Binswanger (1973) took pains to demonstrate the rationality of psychotherapeutic procedures, even though the therapist does not use his or her hands, or any instruments, medication or other physical proceedings. He or she uses only human conversation and stresses the possibility of treating the sufferer only with words. Binswanger's purpose was to free these young people of the very common mistake of thinking that psychotherapeutic work is inappropriate to the reasoning required of scientific culture. Freud (1973a), speaking to the College of Physicians of Vienna, expressed the same concern when he insisted that psychotherapy is not mysticism, nor is it antiscientific and therefore unworthy of interest to researchers.

Simple observation allows one to see a descriptive similarity between psychotherapeutic procedures and religious acts aimed at aiding persons who seek comfort. The most obvious similarity is the use of the word and of listening as therapeutic instruments. As Jackson (1992) stated, this involves the production and management of a type of knowledge that does not necessarily lend itself to the field of vision. Jackson says that the 19th century restored the "emphasis on seeing over hearing, on looking over listening, in the field of sickness and treatment" (ibid.). This perspective, of evidence from seeing, has been consolidated as scientific, and sustains the thinking of a great many of the authors who question the logic and rationality of the psychotherapies. The importance of this perspective has come down unscathed to the present day. Contemporary methods of observing cerebral activity in vivo are methods based on images, and it is not impossible that there be a correlation between these methods and the monitoring of psychiatric treatment, including psychotherapy. The studies by Andreasen et al. (1995) and George et al. (1995) are essential for approaching this problem.

Nevertheless, the authors who study the supposed similarity between religious intervention and psychotherapy based their reasoning on therapeutic procedures that are applied in communities that have not been affected by Western ideological hegemony. Kakar (1994) says that Indian, Islamic and Hindu curers assume that they possess "the ilm, the knowledge of communicating with the divinity, in order to intervene in favor of an afflicted soul". Guyotat (1994) defines a magical procedure "as a technique for capturing symbolic forces, based 


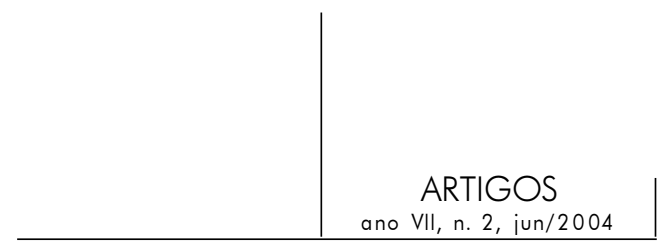

on the conviction that man is able to intervene in cosmic determinism to change its direction". It is through these channels of communication with the divinity, with the possibility of influencing the cosmic order, that primitive healers treat diseases in their communities. According to these etiological propositions, such diseases are caused by the loss of the soul, by demoniac possession, by the violation of a taboo, or other similar occurrences. Levi Strauss (1973a, 1973b) perceiving similarities between shamanic healing and psychoanalysis, limits this latter to an appeal to abreaction and catharsis, required of both the psychoanalysts or shamans, and the patients they treat. Levi-Strauss notes that the similarity can be seen only

... with an inversion of the entire situation. Both practices are aimed at provoking an experience, and both do just this, reconstituting a myth that the sick person should experience, or re-live. But in one case, it is a myth that the sick individual constructs with the help of components taken from his or her past. In the other, it is a social myth that the patient receives from the outside and which does not correspond to an earlier personal state. (1973b)

These references are made here in order to show that one should not confuse the reliance that psychotherapists have on transcendence, by proposing that there is no person who is the immanent product of his or her biology, with the cures that occur in the interior of cultural systems that offer therapy grounded on magic or on the invocation of good and bad spirits. The fact that these primitive therapeutics, besides being based on mysticism, resort to symbolic procedures - which are the components that sustain the merely descriptive similarity mentioned above - does not authority classifying contemporary physicians who practice psychotherapy in this same spirit. It is this spirit that Clare (1979) and Detre (1987) describe as orienting the theory and practice of psychotherapists.

In psychiatry itself, on the other hand, the reference to this style of influence occupies a special place. The factor of communication and personal interrelationship played a central role in the birth of psychiatry. When, in the mid19th century, Pinel took over direction of the hospital of the alienated in Bicetre (1971), he dealt on the therapeutic plane with hygiene, politics and moral qualities. On the etiological plane, he associated organic injuries with moral causes and with environmental influences. He therefore consigned to psychiatry the quality of theoretical questions that instigate it, to wit, pathogenic and therapeutic multiplicity.

It is not incorrect to assert, however, that the first physician who dedicated himself to systematizing psychological influences and structuring them in medical treatment was Sigmund Freud.

In the final decades of the 19th century, Freud treated his patients with hypnosis. Later he developed the cathartic method, but soon abandoned it as he 


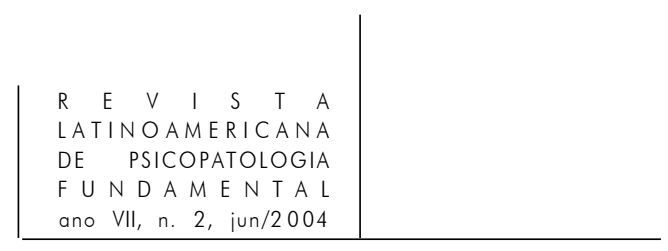

felt that its results were dubious. He then went on to develop psychoanalytic psychotherapy, based on talking in free association. Free association consists of asking the patient to communicate all the thoughts that introspection reveals, abstaining from any logical or affective objections that would lead him or her to select (Freud, 1973b). He recommended an analogous attitude to physicians, which entailed maintaining suspended attention, that is, not concentrating on the purpose of the story being related. The ideology that orients psychoanalytic procedures is the recognition of one or more groups of representations, which are distant from the possibility of association and are therefore unconscious, continue to exercise effects on the individual, in disguised form, in the so-called formations of the unconscious: dreams, symptoms, slips of the tongue, etc. A seal, or a mark of a sexual order characterizes this group of representations. The psychotherapist's function is to decipher these formations in the unconscious, this producing a cure after the patient has worked through what was brought to light during the treatment.

According to some psychoanalysts, this style brought with it a problem: the possible extension of treatment. For this reason, since the 1920s a period that suffered little from the economic pressure that influenced the work of physicians, psychoanalysts began to seek out techniques to shorten treatment. Ferenczi proposed that, to the extent that the progress of the treatment tends to produce limited results, the analyst should insist that the patient face his or her fears and anxieties, renounce narcissistic satisfactions, and define a deadline for the end of treatment. These concerns were based on the possibility that some patients might prefer treatment to cure (Gillièron, 1993), and his perspective led to the development of psychotherapies with analytic inspiration (Machado et al., 1998) and of brief dynamic psychotherapies (Gillièron, 1993; Eizerick et al., 1998), characterized by the choice of a specific focus to guide the therapist's work. The therapist is thus authorized to use interventions of suggestion, encouragement and counseling. Thus, the emphasis that is given in pure psychoanalysis to the revelation of unconscious knowledge, a revelation from which one expects a cure, is displaced to the intentional production of psychic change in the patient.

This style failed to convince all the theoreticians involved in psychotherapy. They felt that this way to conduct therapy, without proof from some extra-clinical tests, would not be in accord with the demands of science. This appeal also began in the early $20^{\text {th }}$ century, in Watson's work, for whom psychoanalysis and its constructions have the scientific status of the miracles of Jesus (Fine, 1981). Watson (1971) was the first researcher to suppose the importance of conditioning to explain mental disturbances. Another pioneer was Wolpe (1972) who, in the 1950 s and 1960s, applied the laws described by the theory of learning to the treatment of serious neurotics, through the reciprocal inhibition therapy. These 


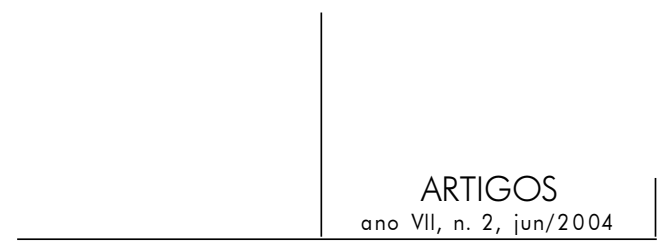

researchers introduced behavior therapy into the psychotherapeutic field and, in contrast to psychoanalysis, constructed their therapeutic proposals not in the clinic with patients, but on the basis of experimental studies on the laws of learning and conditioning in normal persons and in animals, and then applied them to mental disorders (Watson, 1972). According to Eysenck (1974), behavioral therapy makes no reference to unconscious causes, and considers neurotic symptoms as simple habits that have been learned, about which there is nothing to be worked through or discovered. "If we suppress the symptom, we have eliminated the neurosis," says Eysenck (ibid.). Symptoms are understood as badly adaptive conditioned responses originating from learning deficiencies. Cures are obtained by addressing the symptom itself, that is, by extinguishing poorly adaptive conditioned responses and setting up desirable conditioned responses. One of the main therapeutic tools in this field is Wolpe's reciprocal inhibition scheme (Wolpe, 1972), which is based on the study of Sherington's spinal reflexes it obeys the following logic: "If a response that inhibits anxiety occurs in the presence of stimuli which cause anxiety, this response will weaken the connection between these stimuli and the anxiety response" (ibid.). The therapeutic procedure consists basically of discovering the responses that inhibit anxiety. The way to attain this objective is essentially technical and structured, and has no need for personal relationships, which are not essential to the cure. Greenspoon (1972) notes that behaviorism changes the concept of psychotherapy by stressing that the objective of treatment is addressed "to the development and maintenance of specific behaviors that the patient can use to face to his or her environment" (ibid.). This way of organizing the field of psychotherapy gives it limited objectives related to the extinction or development of specific behaviors.

Another line of therapy allied to this behavioral tradition is the cognitive approach, developed by Beck in the early 1960s (Blackburn \& Davidson, 1990). Cognitive therapy is a psychotherapeutic system based on a theory of emotional disorders, and consists of a body of clinical and experimental studies and structured therapeutic techniques. The theory is based on the supposition that "emotion and behavior are determined by the form in which the individual interprets the world" (ibid.). The therapeutic techniques are basically directed toward relief from symptoms through the use of suggestion, teaching, and the means to avoid the difficulties that contribute to suffering. The central focus of cognitive therapy is the solution of problems. The cognitivists add an intermediary step - cognitive processes - to the stimulus/response scheme of the behaviorists. These processes consist of interpretations, thought, perceptions and recollections, which, from the behaviorists' point of view, are regarded as unnecessary, unscientific and irrelevant for understanding behavior (ibid.). Despite this theoretical difference, these two groups are able to work side by side through a 


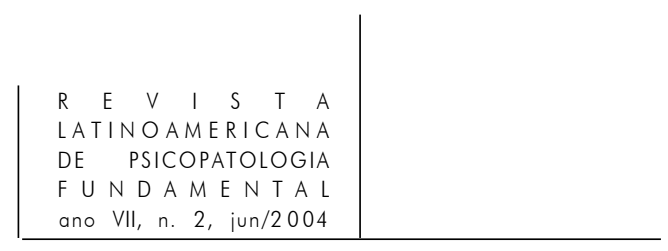

technical approach to the structuring of the psychotherapeutic procedure, and trough limited objectives. They now constitute a monolithic group and exercise a major influence on contemporary psychiatric thought.

\section{Current situation}

It is an undeniable fact that the situation today is divided between those in favor of the cognitive/behavioral, and those who espouse the psychoanalytic/ interpersonal psychotherapeutic styles (Margison \& Shapiro, 1996). As stated above, these procedures have been different in literature and in style since their origin. Those associated with the first group call attention to their origin in the laboratory and proclaim the superiority of empirical and structured schemes. Those associated with the second group are essentially concerned with interpersonal relationships and are satisfied with the few rules that guide their therapeutic schemes. The virtues of one group coincide perfectly with the posture criticized by the other.

As indicated above, however, in the 1980s the various psychotherapies were called on to prove their effectiveness (Marshall 1980a e 1980b) and this appeal constitutes the main change in the work of psychotherapists, who began to respond to these demands. Among these are the presentation of empirical proof of effectiveness, the preparation of manuals that clearly show "how to direct the treatment," guarantees that psychotherapy can be replicated in order to verify the reliability and validity of the technique, the development of procedures that would make therapy brief and show cost-benefit advantages as compared with other medical therapeutics.

So psychotherapists of all affiliations set off to the field to study and prove the effectiveness of their treatment. This process included debates with conceptions which consider that psychotherapy is closer to literary imagination than to science, strictly speaking (Nadelson, 1996) and with others that harbor the suspicion that the positive effect of psychotherapeutic cure is due more to spontaneous remission than to the specific procedures applied by any particular approach (Seligman, 1996). Their implication is that psychotherapy has built up its prestige based more on unspecified effects than on the mechanisms of action so intensely theorized by the psychotherapists. From this point of view, psychotherapy would tend to act like a placebo (Prioleau et al., 1983). In fact, the placebo effect itself has been discussed in clinical essays that study the therapeutic effect of drugs, especially anti-depressives (Enserick, $1999 \mathrm{e}$ Andrews, 2001). The question as to whether psychotherapy can influence human 


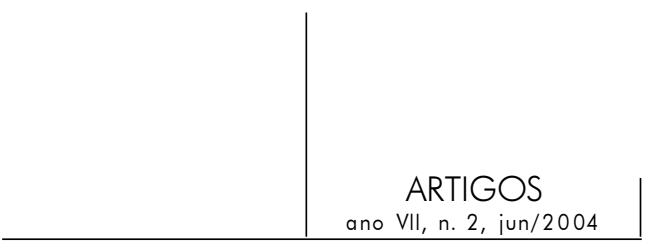

cerebral biology, the arena where pathogenic processes presumably occur, has crowned this sequence of questions.

The research, involving numerous aspects related to psychotherapy, finally demonstrated the clinical usefulness of the procedure.

Andrews (1993), comparing the psychotherapies with placebo conditions, concludes that the "effect size" of psychotherapies reaches its highest level with behavioral psychotherapy (rate of 0.97), but recognizes the superiority of dynamic psychotherapy (74) over counseling (0.35). Tillett (1996) says that the effect size of the psychotherapies reaches a level of 0.8 , similar to anti-depressives. Coursey et al. (1995), directly studying the opinion of severely ill patients, found that $72 \%$ of the respondents (in a sample of 212) report that individual psychotherapy brought about positive changes in their lives, against $28 \%$ who considered it innocuous or prejudicial. In this same study, $16 \%$ stated that medication, provided concurrently with psychotherapy, constituted the most useful procedure, against $25 \%$ who said that therapy through talking helped more. Sixty percent considered that the combination of the two procedures was what made improvement possible. Parsons et al. (1996) discusses two practical guidelines for treating depression, the guideline of the American Psychiatric Association and that of the Agency for Health Care Policy and Research. These authors feel that there has been an "underestimation of the effectiveness of cognitive-behavioral therapy, of brief dynamic psychotherapies, and of group therapies" in the treatment of depression. They also stress that psychotherapy as an exclusive procedure shows effectiveness comparable to other therapeutic resources. McIntyre et al. (1996), author of the guidelines published by the American Psychiatric Association, rejects Parsons's criticisms as fallacious, and asserts that the guidelines are "crystal clear in their unmistakable support to psychotherapies for treating serious depression, considering them effective, on equal ground with anti-depressive drugs and electroconvulsive therapy". The literature has systematically indicated the propriety of applying psychotherapy in acute depressive states (Weissman et al., 1979) to maintain the benefits of the treatment (Weissman, 1994), and in combination with pharmacological treatment (Conti et al., 1986). Conclusions similar to those expressed in these articles are also present when other psychiatric pathologies are studied, such as anxiety disorder (Barlow \& Lehman, 1996), drug addiction (Crits-Cristoph, 1996), and eating disorders (Jaeger et al., 1996). Texts which use meta-analytic statistical techniques arrive at conclusions that also clearly and consistently state that psychotherapies do have a therapeutic effect (Lipsey \& Wilson, 1993; Shapiro \& Shapiro, 1982; Crits-Cristoph, 1992).

Other texts (Bennet, 1988; Borenstein, 1996; Rosemblatt et al.,1992) affirm that the absence of psychotherapy in health plans and organized health-care 


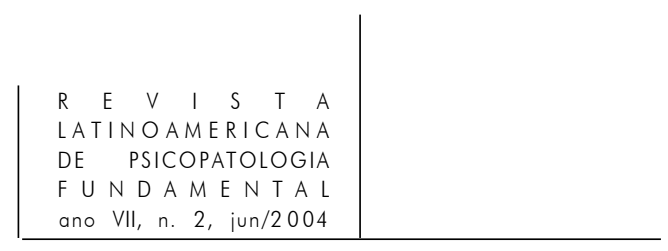

systems is a major factor in characterizing poor evolution and even worsening of clinical situations in focus. They call attention to the fact that, although psychotherapy is a more expensive and more difficult medical procedure, and bears the stamp of being "primitive", since it requires nothing but ordinary contact between two subjects, it has proven to be useful and effective.

\section{Splintering and research in the field of psychotherapy}

Psychoanalysis and the methodological variations which have branched off from it through series a internal dissensions (analytic psychology, existential analysis, psychodrama and others) agree on certain points. One of these is the preeminence given to the clinical encounter, to the point that the knowledge and theory that orient these treatments are defined on this basis. Here the interpersonal relationship is essential as a standard and as a condition for treatment. Another point is the involvement of the patient with his or her treatment. From the point of view of the persons working in these areas, there can be psychotherapy without the notion of responsibility, understood as the subject's ability to respond for his or her acts, thoughts, emotions, love, cowardice and hurts.

Likewise, these methods discuss therapeutic success and failure, and the subsequent evolution of its postulates, from a clinical point of view. Both the patient's and the psychotherapist's resistance, as well as the various modes of intervention, are discussed. It is impossible to appeal to situations outside the clinic that might imitate laboratory conditions. The laboratory is the clinical work itself. In fact, what fulfills this role is the treatment of candidates in training to be therapists, which in no way differs from the usual type of treatment.

With the exception of their forms of brief therapy, the format of these psychotherapies is not based on predetermined objectives, and the pace of the treatment obeys the psychotherapist's ethical direction. There is no predetermined objective, nor is a date for their conclusion defined a priori. The consensus, however, is that treatment should be as brief as possible.

In the 1940s and 1950s, however, the psychotherapeutic field received contributions from psychologists trained in the experimental tradition. They brought to psychotherapeutic activity various procedures that are usually considered the antithesis of the propositions inspired by psychoanalysis.

For this group, the clinical encounter is a moment for applying knowledge, usually developed in experimental studies based on the notion of conditioning and its variants. The chance that knowledge will be produced in the relationship established between psychotherapist and patient is limited to the importance of 


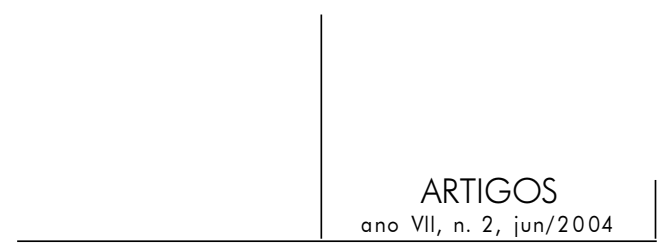

the method of exposing the patient to situations that he or she usually avoids. In this modality, the patient's responsibility is reduced to his willingness to comply with what is proposed to him, with discipline and dedication. These psychotherapies are usually based on predetermined and circumscribed objectives, and the period of treatment is established a priori.

As can be seen, each of these two proposals for treatment is in basic opposition to all the points considered important in the characterization of the other. It is in this regard that one can speak of a clear splintering of the psychotherapeutic field, the most significant division being between psychoanalysis and behaviorism. The first group produced a subdivision using the brief and focus format, while the second group received contributions from cognitive techniques.

Thus, research in psychotherapy, besides concerning itself with internal logic and with the results of the procedures applied and, as has been seen, besides being concerned with proving efficiency in comparison with other therapeutic approaches, is interested in making comparisons between styles in order to ascertain the effectiveness of each and the possibility of differential therapeutic indications.

Russel and Orlinsky (1996) determined four periods in the history of research in psychotherapy. Phase I, from 1927 to 1954, corresponds to the period of establishment of the intention of the research. investigations began to abandon the loneliness of their private offices and were taken to the laboratories. At the same time, instruments for measuring feelings, perceptions, behavior and thinking were developed.

Phase II can be said to have occurred between 1955 and 1969, marked by the solidification of a rigorous scientific field. The study of psychotherapeutic processes became more intense on the basis of the development of objective methods for measuring therapeutic events. The spirit of those involved was encouraged by logical positivism and by empiricism. The validation by consensus among non-participating observers, and the controversial configuration of placebo conditions, were considered scientifically reliable. This scientific development was reinforced by the commitment to set up nomothetic groups with the purpose of guaranteeing control over the experiments. Fisher's statistical methodology, involving the Student-t test, as well as variance analysis, Pearson correlations, and their non-parametric parallels, are used.

Phase III, from 1970 to 1983 , was characterized by the expansion, organization, methodological refinement and introduction of meta-analysis. Comparative studies became frequent. Comparisons among psychotherapeutic styles and between psychotherapeutic and biological interventions became central concerns. Researchers became interested in detecting which aspects of each 


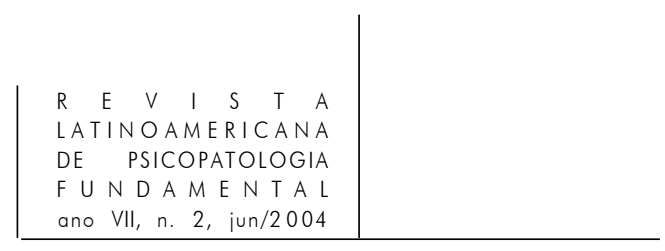

treatment are active or inactive. The therapeutic relationship in itself became the subject of observation, with studies aimed at discerning the various associations between the patient's qualities and the psychotherapist's discursive behavior, in order to identify the relationship of this interaction with the results of treatment. During this same period, a phenomenologically oriented sub-current of research began to gain recognition, and cooperated in the installation of Phase IV, from 1984 to the present. During this period, critical dialogues arose, based on different philosophies of science and their methods of inquiry. Thus, post-positivist models of study began to be debated and work in this vein emphasized discovery over verification. Sampling methods were criticized and considered self-defeating. The most important tendency of these researchers, who were said to be in opposition to the empirical trend, was to call attention to the interrelation complexities and the meaning of the therapeutic relationship.

This brief description of the authors shows the complexity involved in research in this field, a complexity that, although it may not suggest retreat, resists simplification.

In fact, the application of the verificationist empirical method itself is not exempt from a number of reservations. It is not easy to set up conditions that will guarantee that the investigative method used will truly evaluate the characteristic factors of one style or another and that the research will not get lost in determining the importance of what is unspecific in the psychotherapeutic methods analyzed. If the descriptions of the psychoanalytic and behavioral methods clearly explain what is important in one and the other, these sharp differences fade away when the research is carried out.

The point that comes up for the researcher is the possibility of determining an empirical object that satisfies the strict conditions required for research.

So a quick look at what is basic in the empirical methodology indicates that the empiricists, in the context of their research, try to isolate the dependent variables of the therapeutic process to be studied. The dependent variable is that which is undoubtedly associated with the process and is not confused with any other aspect. In the case of the psychotherapies, one must know if the specific actions taken by the psychotherapist are related to the intended results, and this implies an impasse. There is a difficulty involved in isolating the dependent variable and separating it from interference from independent variables which might affect the process, and the very behavior of the dependent variable. Likewise, the variables designated as "foreign" are not adequately isolated. They represent the possibility that factors originating from the counter-hypothesis being tested remain active during the experiment.

Let us take an example. Among the differences between the two rival psychotherapeutic styles is the meaning they give to the presence of the director 


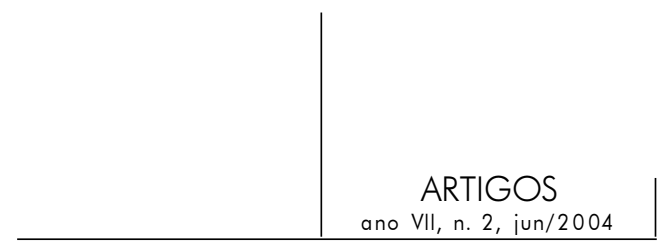

of the process. The cognitive-behavioral psychotherapies propose the hypothesis that the cure of a given patient is a dependent variable of the sophisticated structured instruments of orientation and education they use. The personal characteristics of the therapist and the quality of the relationship between therapist and patient are not seen as determinants of the results of the work, consisting of aspects proper to the foreign variable. However, the competing style, the psychoanalytic, claims that besides what is actually said in free association during the treatment, the personal relationship between patient and therapist corresponds to the dependent variable that may or may not favor the obedience to and adhesion by the patient to the treatment and, therefore, to the production of the cure. Here this personal relationship is imprecisely designated, perhaps vaguely, as transference. The transference, therefore, corresponds to the variable that is "foreign" to the cognitive-behavioral technical procedure. This is one of the possible angles to be considered and, in itself, indicates the complexity of the studies that take psychotherapy as their object.

Therefore, it is clear that, in the name of obedience to the methodology, an experiment that is able to determine the active "component" the dependent variable of the psychotherapy, must in no way confuse the hypothesis with the counterhypothesis. For an evaluation to be valid and reliable, the experiment must contain the logical and pragmatic power to isolate the "active component" of the process being studied, from the independent and "foreign" variables. In the specific case being treated here, the objective is to show that the educational and structured procedure of the cognitivists produces a cure without the intromission of the component known as the transference. It is hard to find an experimental description that has been successful in this endeavor (Woody et al, 1983; Woody et al., 1995; Markowitz et al. 1995).

For Howard et al. (1994), research in psychotherapy presents enough practical holes to cast doubt on the "quality of the results". Therefore, he comments that the random process of choosing does not allow for generalizations and that there is no way of testing why a patient accepts and perseveres in the treatment. Howard's consideration is analogous to the difficulty involved in isolating the dependent variable from the independent and "foreign" variables during testing. He also comments that the varied responses of different patients submitted to the same procedure goes beyond the statistical margin of error. In addition, the psychotherapists are not chosen at random, although they are a decisive factor in a cure through psychotherapy. Pointing out how thorny this empirical ambition is, Howard comments that the loss of data is inevitable and that it is "impossible to standardize any treatment that is conducted in the same direction by the same psychotherapist, on different patients". Sledge (1994) holds that there is a significant difference when psychotherapies are evaluated under 


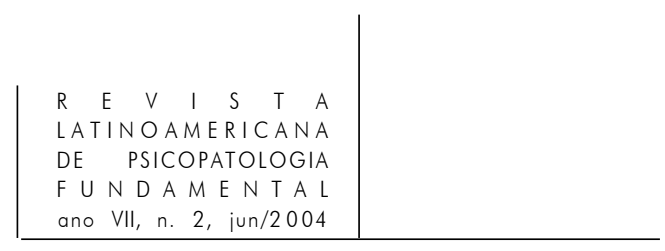

experimental circumstances and when they are evaluated in the "real world," where treatment is conducted under "natural conditions". This involves a discrepancy in numbers rarely found in other fields of experimental science.

In addition, psychotherapy can be considered a complex activity, constructed step by step, and shows no formal linearity appropriate to the experimental environment. Glass (1984) says that

The interpretation of the relationship between the process employed in psychotherapy, and its result, is complex due to the fact that the results can influence the process. Aspects of the psychotherapies usually deemed as independent variables that influence the results (for example, the atmosphere of the treatment and the specific steps taken by the patient and the therapist) can also be affected by the results emerging from the treatment. That is, these variables may be outcomes of the process, rather than causes.

Therefore, the method of evaluation of the psychotherapies must be able to include this diachronic, irreversible temporality, as well as the recognition that the causes and consequences of the phenomenon being studied can reciprocally replace one another, as occurs in phenomena where history is included in their definition. And it is inevitable that the treatment of mental disorders loses more than it gains when it ignores the history that the patient brings along with his or her symptom.

Finally, if the psychotherapies have their value defined solely in this way, their respectability becomes tarnished. Chalmers' (1994) position might be worth recalling here. He says that

... if a given area of knowledge, such as Freudian psychology or Marx's historical materialism, were to undergo a criticism based on the fact that they do not adapt to my characterization of physics, this would imply that all authentic knowledge must adapt itself to the methods and standards of physics. I don't feel prepared to accept this proposition and I think it would be very hard to defend it. I am convinced that there is no atemporal and universal conception of science and of the scientific method that can address the objective of evaluating all pretensions of knowledge. We cannot legitimately defend or reject points of knowledge because they adjust or do not adjust to ready-made scientific criteria.

\section{References}

ANDREASEN, N. et al. Remenbering the past: two facets of episodic memory explored with positron emission tomography. Am. J. Psychiatry, n. 152, p. 1576-85, 1995.

Andreasen, N. Body and soul. Am. J. Psychiatry, n. 153, p. 589-90, 1996. 


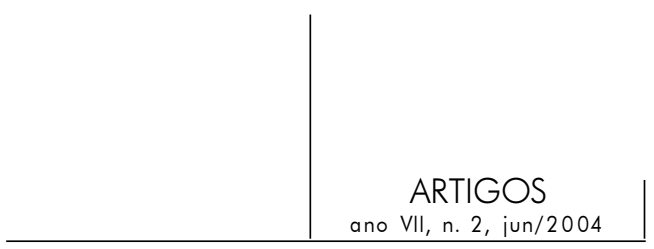

AndRews, G. Placebo response in depression: bane of research, boon to therapy. $B r$. J. Psychiatry, n. 178, p. 192-4, 2001.

The essential psychotherapies. Br. J. Psychiatry, n. 162, p. 447-51, 1993.

Barlow, D.H.; Lehman, C.L. Advances in the psychossocial treatment of anxiety disorders. Arch. Gen. Psychiatry, n. 53, p. 727-35, 1996.

Bennet, M. The greening of HMO: implications for prepaid Psychiatry. Am. J. Psychiatry, n. 145, p. 1544-50, 1988.

Binswanger, L. Sobre psicoterapia (possibilidad e facticidad de la acción psicoterapeutica). In: Artículos y conferencias escogidas. Madrid: Gredos, 1973.

Blackburn, I.; Davidson, K. M. Cognitive psychotherapy for depression and anxiety. A practitioner's guide. Cambridge: Blackwell Scientific Publications, 1990.

Borenstein, D. B. Does managed care permit apropriate use of psychotherapy? Psychiatr. Serv., n. 14, p. 971-4, 1996.

CAmpos, F. C. et al. Pesquisa clínica: a influência da relação médico/paciente. J. Bras. Psiquiatr., n. 50, p. 373-8, 2001.

Chalmers, A. A fabricação da ciência. São Paulo: Unesp, 1994.

Clare, A. Psychiatry in dissent. Controversial issues in thought and practice. Londres: Routledge, 1989.

Conti, H. R. et al. Combined psychotherapy and pharmachotherapy for depression: a systematic analysis of evidence. Arch. Gen. Psychiatry, n. 43, p. 471-9, 1986.

Coursey, A. D. et al. Individual psychotherapy and persons with serious mental illness. Schizophr. Bull., n. 21, p. 283-301, 1995.

Crits-Cristoph, P. Psychossocial treatment for drug abuse. Selected review and recomendations for National Health Care. Arch. Gen. Psychiatry, n. 53, p. 749-56, 1996.

. The efficiency of brief dynamic psychotherapy. A meta-analysis. Am. J. Psychiatry, n. 149, p. 151-8, 1992.

Delgado, H. Curso de psiquiatría. Barcelona: Editorial Científico/Médica, 1969.

Detre, T. The future of psychiatry. Am. J. Psychiatry, n. 144, p. 621-5, 1987.

Eizerick, C. C. et al. Psicoterapia breve dinâmica. In: Cordioli, A.V. (org.). Psicoterapias: abordagens atuais. Porto Alegre: Artes Médicas, 1998.

ENSERINK, M. Can the placebo be the cure? Science, n. 284, p. 238-40, 1999.

Etchegoyen, R. H. Psicoterapia. In: Vidal, G.; Bleichmar, H.; Usandivaras, R.J. (orgs.).

Enciclopedia de psiquiatría. Buenos Aires: El Ateneo, 1977.

Ey, H. et al. Tratado de psiquiatría. Barcelona: Toray-Masson, 1974.

Eysenck, H. J. Teoria del aprendizaje y terapéutica de la conducta. In: Millon, T. (org.) Psicopatologia y personalidad. México: Interamericana, 1974. 


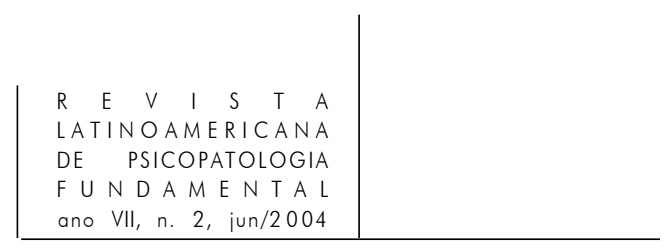

FinE, R. A história da psicanálise. Rio de Janeiro: Edusp/Livros Técnicos/Científicos, 1981.

FREUD, S. Sobre psicoterapia. In: Obras completas. Madrid: Biblioteca Nueva, 1973a. v. I. . Consejos al médico en el tratamiento analítico. In: Obras completas. Madrid: Biblioteca Nueva, 1973b. v. II.

GeORGE, M. S. et al. Brain activity during transient sadness and happiness in healthy women. Am. J. Psychiatry, n. 152, p. 341-51, 1995.

Gillièron, E. Introdução às psicoterapias breves. São Paulo: Martins Fontes, 1993.

Glass, R. M. Psychotherapy: scientific art or artistic science. Arch. Gen. Psychiatry, n. 41, p. 525-6, 1984.

GREENSPOOn, J. Condicionamento verbal e psicologia clínica. In: BaCHARACH, A.J. (org.). Fundamentos experimentais da psicologia clínica. São Paulo: Herder/Edusp, 1972.

Guyotat, J. Estudios de antropología psiquiátrica. México: Fondo de Cultura Económica, 1994.

HowARD, K. I. et al. Clinically relevant outcome research in individual psychotherapy. New models guide the reseacher and clinician. Br. J. Psychiatry, n. 165, p. 4-8, 1994.

JACKSON, S. N. The listening healer in the history of psychological healing. Am. J. Psychiatry, n. 149, p. 1623-32, 1992.

$\mathrm{J}_{\mathrm{AEGER}}$, B. et al. Psychotherapy and bulimia nervosa: evaluation and long-term followup of two conflict-oriented treatment conditions. Acta Psychiatr. Sacand., n. 93, 26878, 1996.

JASPERS, K. Médico e paciente. In: O médico na era da técnica. Lisboa: Edições 70, 1998. . Psicopatologia geral. Rio de Janeiro: Atheneu, 1973. v. II.

KAKAR, S. Chamanes, místicos y doctores. Una investigación psicológica sobre la India y sus tradiciones para curar. México: Fondo de Cultura Económica, 1993.

LÉvi-Strauss, C. O feiticeiro e sua magia. In: Antropologia estrutural. Rio de Janeiro: Tempo Brasileiro, 1973a.

A eficácia simbólica. In: Antropologia estrutural. Rio de Janeiro: Tempo Brasileiro, 1973b.

LiPSEY, M. N.; WiLSON, D. B. The efficacy of psychological, educational and behavioral treatment: confirmation from meta-analysis. Am. Psychol., n. 48, p. 1181-209, 1993.

Machado, S. C. E. P.; VAsconcellos, M. C. E. Psicanálise e psicoterapia de orientação analítica. In: Cordioli, A.V. (org.). Psicoterapias: abordagens atuais. Porto Alegre: Artes Médicas, 1998.

Mann, D. W. The question of medical psychotherapy. Am. J. Psychotherapy, n. XLIII, p. 405-13, 1989. 


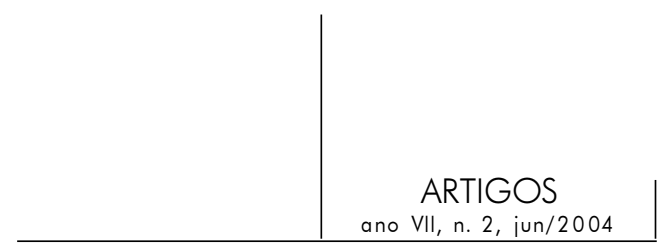

Margison, F. \& Shapiro, D. Psychological treatments for depression (letter). Br. J. Psychiatry, n. 168, p. 127, 1996.

Markowitz, J. C. et al. Individual psychotherapies for depressed HIV-positive patients. Am. J. Psychiatry, n. 152, p. 1504-9, 1995.

Marshall, E. Psychotherapy faces tests of worth. Science, v. 207, n. 4426, p. 35-6. 1980a.

Psychotherapy works, but for whom? Science, v. 207, n. 4430, p. 506-8, 1980 b.

McIntyre, J. S. et al. The role of psychotherapy in the treatment of depression. Commentary. Arch. Gen. Psychiatry, n. 53, p. 291-3, 1996.

Mohl, P. et al. Psychotherapy training for the psychiatrist of the future. Am. J. Psychiatry, n. 147, p. 7-13, 1990.

Nadelson, T. Psychotherapy, revelation, science and deep thinking. Am. J. Psychiatry, n. 153 (Suppl), p. 7-10, 1996.

Nobre de Melo, A. L. Psiquiatria. Rio de Janeiro: Civilização Brasileira/MEC, 1979. v. II.

PARsons, J. B. et al. The role of psychotherapy in the treatment of depression. Review of two practice guidelines. Arch. Gen. Psychiatry, n. 53, p. 283-90, 1996.

Pelicier, Y. História da psiquiatria. Lisboa: Europa/América, 1971.

Prioleau, L. et al. An analysis of psychotherapy versus placebo studies. Behavioral and Brain Sciences, n. 6, p. 275-302, 1983.

Ramadam, Z. B. A. Psicoterapia. São Paulo: Ática, 1987.

Rosemblatt, A. D. et al. Psychotherapy in the Future. Commitee on Therapy - Group for the Advancement of Psychiatry. USA: American Psychiatry Press, 1992.

Russel, R. L. \& Orlinsky, D. E. Psychotherapy research in historical perspective. Implications for health care policy. Arch. Gen. Psychiatry, n. 53, p. 708-15, 1996.

Seligman, M. E. Science as an ally practice. Am. Psychol., n. 51, 1072-1079. 1996.

Shapiro, D.A. \& ShapIRo, D. Meta-analysis of comparative therapy outcomes studies: a replication and refinement. Psychological Bulletin, n. 92, p. 581-604, 1982.

Sledge, W. H. Psychotherapy in US I: challenges and opportunities. Am. J. Psychiatry, n. 151, p. 1267-70, 1994.

Tillett, R. Psychotherapy assesment and treatment selection. Br. J. Psychiatry, n. 168, p. 10-5, 1996.

Watson, J. B. O comportamentismo. In: Herrnstein, R.J. \& Boring, E.G. (orgs.). Textos básicos de história da psicologia. São Paulo: Herder/Edusp, 1971.

Watson, R. I. A tradição experimental e a psicologia clínica. In: BACHARACH, A.J. (org.). Fundamentos experimentais da psicologia clínica. São Paulo: Herder/Edusp, 1972.

Weissman, M. M. et al. The efficacy of drug and psychotherapy in the treatment of acute depressive episodes. Am. J. Psychiatry, n. 136, p. 555-68, 1979. 


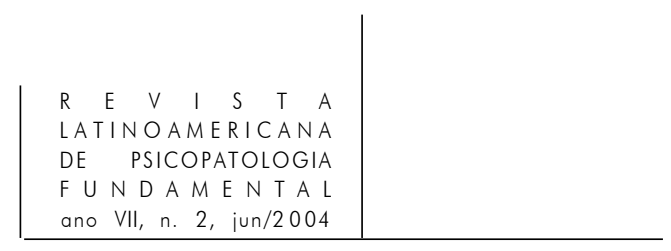

Weissman, M. M. Psychotherapy in the maintenance treatment of depression. Br. J. Psychiatry, n. 165 (suppl. 26), p. 42-50, 1994.

WIENER, J. M. Response to the presidential address: roots, diversity and professional identity. Am. J. Psychiatry, n. 151, p. 1262-4, 1994.

WoLPE, J. As bases experimentais de alguns novos métodos psicoterapêuticos. In: Bacharach, A.J. (org.). Fundamentos experimentais da psicologia clínica. São Paulo: Herder/Edusp, 1972.

Woody, G. E. et al. Psychotherapy for opiate addicts: does it help? Arch. Gen. Psychiatry, n. 40, p. 639-45, 1983.

Psychotherapy in communitty methadon programs. Avaliation study. Am. $J$. Psychiatry, n. 152, p. 1302-8, 1995.

\section{Resumos}

O autor discute alguns dos aspectos associados ao exercício da psicoterapia. Defende a racionalidade do procedimento, comenta sobre o fracionamento do campo psicoterapêutico e discute a conveniência da aplicação da metodologia científica a este ramo do saber.

Palavras-chave: Psicoterapia, psicanálise, pesquisa, ciência

El autor discute algunos de los aspectos asociados al ejercício de la psicoterapia. Defiende la racionalidad del procedimiento, comenta sobre el fraccionamiento del campo psicoterapéutico y discute la conveniencia de la aplicación de la metodologia científica en este ramo del saber.

Palabras clave: Psicoterapia, psicoanálisis, investigación, ciencia

L'auteur discute certains aspects associés à l'exercice de la psychothérapie. Il défend la rationalité de la procédure, commente le fractionnement du champ thérapeutique et discute la convenance de l'application de la méthodologie scientifique à ce domaine du savoir.

Mots-clés: Psychothérapie, psychanalyse, recherche, science 